Marquette University

e-Publications@Marquette

Theology Faculty Research and Publications

Theology, Department of

$1-1-2015$

\title{
Sacraments in the Lutheran Reformation
}

Mickey L. Mattox

Marquette University, mickey.mattox@marquette.edu

Published version. "Sacraments in the Lutheran Reformation," in Oxford Handbook of Sacramental Theology. Eds. Hans Boersma and Matthew Levering. Oxford, United Kingdom and New York, NY: Oxford University Press, 2015: 269-282. Publisher Link. (C) 2015 Oxford University Press. Used with permission. 


\title{
SACRAMENTS IN THE LUTHERAN REFORMATION
}

\author{
MICKEY L. MAT TOX
}

THE Lutheran Reformation transformed all aspects of Christian life and experience in the regions where it was adopted, not least in the area of the sacraments. As opposed to the seven sacraments of the medieval Catholic Church, the Lutheran reformers quickly settled on only two: baptism and the Lord's Supper (Eucharist). Nevertheless, Lutheranism remained very much a sacramental religion in terms of the practices and piety surrounding these two central, Christian rites. Both the change and the continuity one finds in Lutheran sacramentalism have their origins in the life and thought of Martin Luther as it was carried through in the Lutheran confessional writings, in the various Lutheran church orders, and in Lutheran theology.

In spite of the changes brought to sacramental theology by the Lutheran reformers, their church practice was characterized by a vigorous and distinctive commitment to the sacraments as means of grace. Following the lead of Martin Luther, the Lutheran churches emphasized the lifelong validity of baptism, which was in the ordinary course of life to be received as an infant and afterwards persistently reclaimed as the sure ground of the believer's salvation, given from without. The Lutheran reformers also developed a distinctive eucharistic realism, which emphasized the regular reception of Christ's body and blood for the forgiveness of sin, the strengthening of faith, and as mystical participation in the church's risen Lord. Indeed, on the Lutheran account the church itself was instituted for the purpose not only of the right proclamation of the gospel, but also for the proper administration of the life-giving sacraments. If the gospel is about Christ, moreover, then so too are the sacraments. Indeed, Christ himself is the one true sacrament.

The Lutheran Reformation brought with it not only theological but also liturgical reforms. The latter entailed significant changes in the structure of the mass, as well as a new hymnody, much of it devoted to the sacraments, so that congregational singing functioned both to teach Lutheran sacramental theology and to deepen Christian experience (Brown 2008). While the Lutherans rejected five of the traditional 
sacraments, they nevertheless continued in modified form the practices of confirmation, of private confession, of Christian marriage, of ordination into the Church's ministry of Word and Sacrament, and of ministering the Lord's Supper to the sick and dying. Although these five important ritual actions were not understood as sacraments in the strict sense, orders for their administration were included in Lutheran church regulations and service books. Thus, in the Lutheran churches they remained decisively Christian practices that shaped the lives of countless Lutheran faithful. The Lutheran Reformation's critical reduction of the number of the sacraments did not, therefore, entail a reduction in the scope of Christian experience; still less was it intended as a first step in secularization. To the contrary, it was accompanied by a broad determination to more deeply Christianize both the individual experience of Christian faith and the Christian societies in which the Lutheran reforms were adopted (Hendrix 2004).

\section{BACKGROUND}

The Lutheran movement emerged during a difficult period in the church's history, and as a direct consequence of a crisis that was initially centered in the sacrament of penance. This crisis itself had extensive social and political, even military, implications, that multiplied the complexity of an already difficult set of theological questions. It is important, therefore, to recount some of this history in order to make clear the fundamentals of Lutheran sacramental theology and practice. The age during which Lutheranism's formative development occurred, moreover, was marked by a climate of extreme mutual vilification between the Lutherans and their opponents, on both the Catholic and on the Protestant sides. The controversies of these bygone times testify not only to theological division, but to a failure of the bond of Christian charity as well.

The Lutheran Reformation began with Martin Luther's proposal of a series of academic theses for debate concerning the sacrament of penance, and especially the church's practice of offering indulgences, on All Saints' Day in October 1517 (Brecht 1985: 190-202). Scholars have debated for a generation now the question whether the theses were actually posted on the door of Wittenberg's Castle Church, a story and an image that loom large in Lutheran lore (Lohse 1986: 42-4). It now seems likely, however, that Luther did something much less dramatic, and that his "Ninety-Five Theses" became an accidental overnight sensation when, quite without his permission, they were published and news of his objections to the practice of indulgences spread far beyond his native Saxony (Leppin 2007). In any case, the theses posed a series of difficult questions about a practice that was clearly open to abuse, and about which the church's critics, including Luther's later Catholic opponent Cardinal Cajetan, had frequently complained (Bagchi 2006). Is there a danger that indulgences can lead to a false sense of complacency in the Christian life? Does the pope's earthly jurisdiction over the faithful, as well as his exercise of the "office of the keys" (power to forgive sins based on Matthew 16), extend also 
beyond this life, even to the departed dead suffering in purgatory? Why spend money to buy one's way out of purgatory while the poor are still in need?

The most fundamental of Luther's objections to indulgences was arguably to be found in the first of the theses, where the pious young Augustinian professor of Bible insisted that the entire life of the Christian should be one of repentance. Jesus' exhortation to "repent and believe the gospel," in other words, meant not that the Christian should occasionally go to the sacrament of penance, but rather that the gospel itself should initiate the Christian into a new way of life whose central identifying mark is the humility of daily repentance (Luther's Works 31: 25). Luther may also have been motivated by pastoral concern that some simple Christians would be deceived by the benefits attached to some indulgences and so develop a false sense of security, one that would suggest they could afterwards avoid the hard work of this lifelong repentance.

There were good reasons for Luther's concerns. An indulgence being preached that year in nearby territories offered full ("plenary") remission of the punishments owing for $\sin$ (and thus from the torments of purgatory) based on a sliding contribution scale with an amount fit for everyone from the poorest peasant to the richest noble. This particular indulgence had been approved by Pope Leo X as a fund-raising program for Archbishop Albrecht of Brandenburg, who had recently added to his titles that of the archbishop of Mainz after he agreed to make a sizable contribution (21,000 ducats, borrowed from the Fugger banking house) to the Roman see based on the proceeds of a special indulgence sale (Brecht 1985: 175-183). Luther was unaware of these financial arrangements, but was deeply concerned with what he saw as the false promises and errant theology associated with indulgences. Again, Luther was hardly the first to express such concerns, but the controversy sparked by his theses soon set off a firestorm and inscribed the rejection of indulgences indelibly on his person.

The debate over indulgences between Luther and his many opponents expanded almost immediately to include the issue of authority, particularly that of the pope. In 1520 , after a series of tense and personally threatening encounters with theologians representing, in one way or another, the Roman Church, Luther reached a crucial juncture. In 1517 Ulrich von Hutten (1488-1523), a knight of the lesser German nobility, brought into print for the first time a scandalous exposé written by the Italian scholar, Lorenzo Valla (1407-1457), On the Donation of Constantine (Whitford 2008). This work, which Valla himself had considered too dangerous to publish, demonstrated that the socalled "Donation" was, at best, a pious forgery. It purported to document the Emperor Constantine's gift to Pope Sylvester I of the imperial power, including "all provinces, localities and towns in Italy and the western hemisphere." The document, in short, made the papacy a secular power. Luther read Valla in February 1520, and as a consequence he became deeply suspicious of the Roman curia, particularly what he saw as their greed and lust for power. A new and more fundamental critique of the church's sacramental system, suffused with an undercurrent of apocalyptic outrage, soon followed.

In June 1520 Luther was threatened with excommunication in the papal bull Exsurge Domine (Brecht 1985: 389-396). He.responded with a flurry of treatises. In August, his Appeal to the Christian Nobility of the German Nation asked the nobles to take charge of 
the reform of the churches in their territories on the basis of the priesthood given them in baptism. This appeal seemed in the eyes of representatives of the Roman Church to constitute little less than a handover of the church's own authority to the secular powers. In the light of the long medieval struggle regarding the "two swords" of ecclesiastical and secular power, moreover, it seemed a capitulation to everything the church had been struggling against for the past four centuries.

\section{REFORMING THE SACRAMENTS}

In October Luther published the ominously-titled Prelude on the Babylonian Captivity of the Church, an explosive and radically revisionist tract that called for a thoroughgoing reconfiguration of sacramental theology and practice, both of which he believed had been corrupted when they were integrated into a broad scheme of ecclesial revenue production in which fees and contributions were connected to sacramental graces. Although the Babylonian Captivity was written during a period of distinct religious and existential angst, and under the shadow of a growing apocalypticism, Luther's positions on the sacraments almost immediately became the abiding positions of the Lutheran tradition. Indeed, as one leading scholar puts it, in the Babylonian Captivity of 1520 we find the "final formulation of the Reformation understanding of the sacraments" (Brecht 1985: 380). Nevertheless, a good deal of development and controversy still lay ahead for Luther and his Lutheran followers, as they strove to fashion out of his original protest a durable theological and ecclesial tradition.

As reflected in the Babylonian Captivity, Luther's first steps were critical, even apocalyptic. Simony, he figured, had become nothing less than regular practice in the church, and the papal curia had given themselves over to unbridled greed. How else, he thought, could the church herself have come to persecute the very gospel for whose sake she had been founded? In the Babylonian Captivity, Luther argued for the reduction of the church's traditional seven sacraments, first to three (including penance), but finally to only two: baptism and the Lord's Supper. A crucial criterion for this reduction was institution by the Lord of the church, Jesus Christ, in association with a promise of grace. Wherever God deals graciously with humankind, Luther argued, he attaches a sign to the gift of grace. In the case of the covenant with Abraham, for example, God gave the sign of circumcision, while to the promise not to destroy the world again by a flood God attached the rainbow. Likewise, Jesus instituted both baptism and the Lord's Supper, Luther thought, as external signs of the grace and salvation he had promised through them. There was some theological precedent for Luther's argument for only two sacraments. In the medieval Latin tradition, for example, Peter Lombard's Sentences had allowed that one could distinguish the "sacramenta maiora," baptism and Eucharist, from the remaining "sacramenta minora." Even the two "major sacraments" Luther allowed to stand, however, required substantial theological and, eventually, ritual adjustment. 


\section{Sacraments Rejected}

In the Babylonian Captivity, Luther flatly rejected five of the church's traditional sacraments. He did not deny their ritual importance, but he saw the church's elevation of these important rites to sacramental status as motivated by greed and a desire for control. In the case of penance, for example, he found private confession a helpful practice and commended it as such. However, he dismissed mandatory private confession to a priest on grounds that Christ in Matthew 18 had given to the faithful both individually and collectively the duty and power to assure one another of the forgiveness of sins. Confession to a brother or sister in the faith is therefore just as valid as confession to a priest, for by virtue of their baptism all Christians belong to the spiritual priesthood. Similarly he found that ordination had no instituted rite and divine promise. Instead, he found this "sacrament" an invention of the church, which, he argued, as a "creature of the Word," has no power to institute new sacraments. He also rejected arguments for an "indelible mark" on the priest's soul imparted in the rite of ordination. To be sure, Luther himself and the later Lutheran tradition would afterwards take care to underscore the necessity that a priest or pastor should be "rightly called" (rite vocatus) and ordained in order to carry out the public functions of the ministry, and even that this ministry was to be exercised "over against" the congregation of believers and not merely in their stead or, still less, at their command. No matter how necessary those functions might be, however, they did not understand installation into the public ministry as a sacrament through which the Lord had promised saving grace. Luther also criticized the "reservation" of the forgiveness of certain grave sins to the papacy, partly on grounds that this practice required the confessor to reveal the confessed sin to a superior.

$\mathrm{He}$ found further that confirmation and marriage, though commendable practices, did not have associated with them a divine promise. Hence, they lacked divine institution as a sacrament. Per Ephesians 5, however, he allowed that marriage is a "material allegory" of the love between Christ and the church. Significant adjustments, he thought, needed to be made to the traditional rules concerning proposed marriages between blood relations (i.e. consanguinity). Likewise he found no divine institution or related promise of grace in the prayer of anointing ("Last Rites"). Lutheran Christians would continue to live, and to die, as Christians, but they would not understand the church's ministrations to the dying, important though they surely were, as a sacrament in the strict sense.

\section{Baptism}

Baptism, on the other hand, was moved to the center of the Christian life. Already in the Babylonian Captivity Luther argued that it should be seen as a sacrament whose grace could never be "sinned away," not even through mortal sin. Its abiding validity meant that those who sinned away the Spirit could be restored to a state of grace 
through a repentance that led them not beyond baptism-as a "second plank after shipwreck," as Tertullian put it-but back to it, to grasp hold of it again in faith as the very source of their Christian life. The sacrament of penance, therefore, was not done away with but resolved into a return to the grace of baptism, which suggests why the practice of private confession, though no longer understood as a sacrament, remained vital within the Lutheran churches (Rittgers 2004). Luther's teaching in the following years remained remarkably consistent with these early pronouncements, but it was extended, applied, and further developed, particularly in his Small and Large Catechisms, as well as in the Lutheran confessional writings (Kolb and Wengert 2000).

In his own later work, Luther articulated a theology of baptism that made clear its deep continuity with the antecedent theological tradition, albeit with a number of distinctive accents (Trigg 1994). Baptism is valid and effective, on Luther's account, because it is founded on God's own unbreakable word of promise, and it effects the forgiveness of sin. The faith of the Christian community gathered at baptism holds to God's word of promise, such that in the sacrament God conveys new life and regeneration in the Holy Spirit. Luther cites often and with satisfaction the traditional wisdom of Augustine that "when the word is added to the element it becomes a sacrament." Baptism thus has an objective validity in Luther's theology, regardless of his rejection of the medieval notion that the sacraments of the New Testament excel those of the Old Testament because they work not ex opere operantis but ex opere operato. To be sure, on Luther's account the faith of the baptizing church is necessary for the sacrament, as is the baptizand's own subjective appropriation of the gift of faith. To that extent in Luther's baptismal theology one finds an element of subjectivity, of cooperation, and even reciprocity. The work that is accomplished in the sacrament itself, however, is strictly divine, which means that the Christian can always look back on his or her own life as having begun and being perpetually established upon the firm ground of God's own word and work, alone. Baptism thus becomes the Christian's strongest bulwark against the dark night of the soul, when the devil tempts one to believe that her sins are too great, and that she will be lost. Against the demonic voices of temptation and despair one can ever turn, and return, to the gift of salvation given, one's present faults and failings notwithstanding, at the baptismal font.

The abiding significance of baptism, therefore, consists in its establishment in the Christian of that life of perpetual repentance mentioned so prominently in the NinetyFive Theses. The true and daily repentance that marks authentic Christian existence therefore means nothing less than a return to baptism, and ipso facto a reappropriation of the grace once given. At the same time, however, baptism in Luther's theology also initiates a life of renewal, which is understood as one's daily putting to death of the "old Adam" in order that, in Christ, the "new Adam" might rise. In this sense, justification in Luther's theology already includes sanctification, as well as a recognition-indeed, an insistence - that the Christian life itself includes a Spirit-led dynamism that moves the believer ever forward toward holiness; toward, that is, the completion of the good work that was begun in one's baptism. This reality as a whole, moreover, is founded upon the 
sacrament and is therefore fully ecclesial. Consequently, the church with her preaching of the gospel and administration of the sacraments is the sine qua non of the Christian life as such. Much as one begins the life of faith in the gathered company of the faithful, so also that life is ever renewed and strengthened there. Return to baptism means return to church; both the church and her sacraments are necessary for salvation, for as Luther writes, "the church is the mother that begets and bears every Christian through the word" (Kolb and Wengert: 436).

In so far as Luther's baptismal theology is ecclesial, then, it is also communal. Indeed, Luther's sense of a communal Christian solidarity in this sacrament includes not only the here and now, but also the long tradition of Christian faith and faithfulness. Thus, in the Large Catechism (1529) Luther could look back to the church's own faith and tradition to prove the practice of infant baptism, a practice the Lutheran churches enthusiastically continued. Is infant baptism right and valid? Rather than turning to a series of biblical proof texts to answer this question, Luther instead appealed to the evident faith of those many great saints who were themselves baptized as infants. Can one doubt that, for example, St. Bernard had the Spirit? The Spirit is promised in baptism, moreover, so Bernard's infant baptism, together with those of a great host of other saints, must have been effective, particularly when one takes into account their clear and sometimes even heroic faith.

This aspect of Lutheran baptismal theology reminds us that in an era of rapid ecclesial change Lutheranism soon found itself in between the emerging confessional families, opposed on the one hand by Catholics and on the other hand by a developing array of the new Protestant traditions. The Anabaptists were prominent among the latter, and they generally held that baptism is an external rite that testifies to an internal change of heart, repentance, that can be expected only of those old enough to make a decision for or against faith. The Anabaptists rejected infant baptism, and for that and other reasons, particularly their refusal of oaths, they faced fearsome persecution from both Catholics and Protestants. Luther's continuation of the practice of infant baptism, in defense of which he himself would sometimes appeal to "infant faith" (Huovinen 1997), therefore reflects not only his deep theological satisfaction with the fact that the Christian life begins in utter helplessness, with a word of God that comes from without to claim and transform the believer, but also a hermeneutical approach to the reception of liturgical traditions that does not always ask whether a particular practice is clearly commanded in Scripture, but seeks rather to discern whether that practice coheres well with the faith and sacramental life clearly established in Holy Scripture. To this extent, the approach of the Lutheran Reformation to the broader nexus of ritual life and practice within which the sacraments themselves are embedded differs significantly from what is found in some other Protestant traditions, where, for example, only the psalter is to be sung in church, per scriptural injunction. Luther's more broadly affirming approach, where traditional practices may be retained so long as they are not forbidden by Scripture, alerts us to the fact that the Lutheran Reformation was not iconoclastic, either in its reception of ecclesial art and music or in its approach to sacramental life and practice. The resulting continuities between emerging Lutheran church life and that of 
the medieval Catholic tradition are striking, even if one recognizes that powerful, lifeshaping changes were afoot as well.

\section{The Lord's Supper}

In the Babylonian Captivity, Luther argued that the Lord's Supper could be properly understood neither as a good work nor as a sacrifice that earned merit before God, but instead as the gracious action through which God offers the benefits of grace to the faithful through this, the last Testament of Christ: beneficium, sed non sacrificium. Luther complained, moreover, that the doctrine of transubstantiation purported to explain philosophically what should rather be left a mystery known only to faith, the true presence of Christ in his body and blood in the Lord's Supper. Why add the "miracle" of the annihilation of the bread and wine to the true and essential miracle of Christ's presence in the bread and cup? Nor could he find justification for the church's practice of withholding the cup from the laity. Communion in one kind, distributing the bread only, he argued, is inconsistent with the clear commands of Christ that participants should both "take and eat" and "take and drink." Nor, Luther thought, is it right to describe the mass as an opus operatum, because living faith, as in the case of baptism, is necessary for its worthy reception. It is not enough, he thought, to come to the sacrament unburdened by the obstacle of mortal sin. Rather, one ought to come in true and living faith, aware of what is to be offered and received.

In his later work, particularly his two catechisms, however, Luther was pressed not to allow proper subjective preparation for the sacrament to overwhelm its de facto reality, even apart from subjective faith. Thus, he defended the reality and objectivity of the sacramental presence of Christ on the basis of Christ's own words of promise. The sacrament offers and all who participate-the worthy and the unworthy alike-receive the true body and blood of Jesus Christ. Nevertheless, as in the sacrament of baptism he continued to insist on subjective faith, not as the means of making Christ present, but as requisite for "worthy" reception of the sacrament, that is, for life and salvation. Indeed, on Luther's account the "sacrament of the Altar" offers the forgiveness of sins. Just as Christ poured out his body and blood on the cross to effect the forgiveness of sin, so here he does the same. All who receive the sacrament thus receive its benefits. This sacrament, moreover, strengthens faith and in just that way nurtures the life of faith. Luther also urges frequent reception of communion, for only a faith strengthened by the true body and blood is fit to carry on the daily struggle against the old Adam. The life of repentance and renewal depends vitally on the most effective presence of the saving Christ, given in the Lord's Supper.

Luther's understanding of the Lord's Supper met opposition, however, not only from Catholics but also from other church reformers. In April 1521, not long after his excommunication in January 1521, and only a few months after the Babylonian Captivity, Luther appeared before the Imperial Congress ("Diet"), meeting under the leadership of the newly crowned emperor, Charles V. A few days afterward, the congress issued 
the Edict of Worms, which declared Luther an outlaw and heretic and forced him into hiding at the Wartburg Castle under the protection of his prince, Frederick the Wise. Back in Wittenberg, however, church reform continued, now under the leadership of Luther's colleague, the theologian Andreas Bodenstein von Karlstadt (1486-1541). Karlstadt's vision for reform was at once more radical and more spiritualistic than that of Luther, and in that respect he had much in common with the so-called "Zwickau Prophets," three visionary reformers who emphasized the direct inspiration of the Holy Spirit. For his part, Karlstadt thought that massive liturgical reform was mandated by divine law. With the agreement of the city council some of these reforms were instituted, and social unrest, including episodes of iconoclasm, soon resulted. These "radical" approaches to reform helped set Luther on a more moderate path (Brecht 1990: 34-38). In early 1522 he returned to Wittenberg where he took up the mantle of leadership, stilled the social unrest, and instituted a more measured pace of reform in which liturgical change was understood as a matter of evangelical freedom.

Thus Luther found himself throughout the 1520 s at the center of sacramental controversies, and for the most part they had to do with church reformers who urged more radical approaches. Luther and most of these other reformers agreed broadly that baptism and the Lord's Supper are the two valid sacraments. Where Luther affirmed the true presence of Christ's body and blood in the Lord's Supper, however, others adopted a spiritualist doctrine derived in different ways from both St. Augustine and the humanist scholar, Desiderius Erasmus of Rotterdam (1466-1536). In a few short years the controversy between Luther and the Swiss exploded into a pamphlet war, primarily between Luther and Zwingli. In a short time, moreover, it became apparent that the controversy over the Lord's Supper had profound and potentially divisive consequences in Christology. Zurich's Ulrich Zwingli was an original and independent church reformer, who had also opposed indulgences. He articulated a spiritual memorialism, which, as noted above, seems to have been derived in roughly equal parts from both St. Augustine ("believe and thou hast eaten") and Erasmus' philosophia Christi, which was rather deeply indebted to a broadly Platonist dualism. Luther, on the other hand, defended the reality of the sacrament as Christ's very body and blood. The particulars of the inner-Protestant controversy over this sacrament are important, for they reveal the depth of the Lutheran commitment to "real presence" and, more specifically, the dense network of connections between Lutheran Christology and eucharistic theology.

In this matter, the interpretation of John 6 was crucial. Luther argued that this text could not be understood as applying to the Lord's Supper. Zwingli and his followers, however, seized on Christ's words there that "the flesh profits nothing" to advance their view that what matters in the Supper is that believing hearts together feed on Christ in the Holy Spirit. The presence of Christ as they understood it is brought to the Supper, internally, within the hearts of the faithful rather than received by them, externally, from the hands of the minister. The Zwinglian side in this controversy was also deeply impressed by a letter written by Cornelius Hoen (c. 1521), which, borrowing significantly from Hussite eucharistic teaching, offered a thoroughgoing critique of Catholic eucharistic theology (Oberman 1966: 268-278; Burnett 2011: 83-90). Perhaps most 
importantly, Hoen argued that the verb in the crucial words of institution, the Latin "est" in the phrase hoc est corpus meum, should not be taken literally. Instead, it should be understood with the Latin significat, as in "this signifies my body ... my blood." Zwingli was joined in his efforts by the capable humanist and reformer of Basel, Johannes Oecolampadius (1482-1531), who sought through his knowledge of the church fathers to demonstrate that the Zwinglian understanding was consistent with the ancient faith.

In a word, Zwingli and Oecolampadius saw the Lord's Supper as a memorial meal, one that commemorates but does not celebrate. They rejected, in other words, not only eucharistic sacrifice, as per the Babylonian Captivity, but also eucharistic presence. A crucial problem here was the humanity of Christ. His true humanity, these reformers argued, requires a body like ours in every way, which includes its finitude in regard to space and time. If Christ's humanity, including his body and blood, is really like our own, then it cannot be in more than one place at one time. These reformers therefore rejected any realistic understanding of the Lord's Supper. There is no elemental change (metabole) in the bread and wine of the Lord's Supper, and those who insist that there is come perilously close to the sin of idolatry when and if they venerate the Christ supposedly present in the eucharistic bread and cup (artolatreia).

Luther reacted explosively to these claims, so much so that it left observers, then and now, at some pains to understand why. It seems that for Luther, whose spiritual geography had no middle ground, the Swiss were simply "Sacramentarians," that is, unbelievers who denied the efficacy of the external means of grace. Thus, after they met at the failed Marburg Colloquy in 1529 Luther seemed to dismiss Zwingli: " $[\mathrm{H}] \mathrm{e}$ has another spirit." Luther's point seems to have been that Zwingli and his followers were rationalizers who were unwilling to attend to the plain sense of the Bible. More importantly Luther believed that the status of the sacraments as the external and unique means of saving grace were at stake in this controversy. Put differently, on Luther's understanding Zwinglian spiritualism eventually cuts the believer off from the objective word and promise of grace that comes from "outside us" (extra nos), in the external word and sacraments. One is forced, therefore, to turn inward in a subjective search for grace and assurance, which on account of sin must remain ever elusive apart from the external sacraments. Whereas for Zwingli the Holy Spirit needs no means, for Luther the Spirit employs the very means God has ordained, drawing us to Christ's true body and blood, which are to be found precisely where the Lord in his own words has promised them to be: in the church, at the table, and in the bread and the cup. When we add to that, moreover, Luther's clear teaching that the Spirit leads us to Christ in order to show us the Father's heart then we are in a position to appreciate the Trinitarian shape of his theology of the Lord's Supper, which gave due attention to the internal, subjective side of the sacrament even while insisting upon its visible and external side too, where the consecrated elements become the "visible words" of God.

Just one year after Marburg, the Lutheran reformers under the theological leadership of Luther's younger colleague Philip Melanchthon offered a theological explanation of the reforms undertaken in Lutheran territories to the Imperial Congress gathered in the German city of Augsburg. This "Augsburg Confession" of the faith submitted by the 
reforming Protestant princes subsequently became one of the definitive "confessional" statements of the Lutheran Reformation, even though it was rejected by the congress. The emperor ordered a confutation from the Roman side, which on the subject of the Lord's Supper offered a lukewarm affirmation of the Lutheran teaching that in the bread and cup the body and blood are "truly and substantially present." At the same time, it also criticized the Lutherans for avoiding the doctrine of concomitance, which had been used to defend the Catholic practice of communion in "one kind," that is, the distribution to the faithful of the bread only, with the understanding that the body and blood of Christ are truly and equally present under either of the eucharistic species (Kolb and Nestingen 2001: 112). By the end of 1530, then, the Lutheran reformers found themselves positioned somewhat uncomfortably between the spiritualizing reformers of South Germany and Switzerland, and the Catholic defenders of the "old faith." This situation persisted throughout the Reformation period, and it led eventually to the reification of intra-Protestant theological difference into two competing "magisterial" traditions, the Lutheran and the Reformed.

Returning once again to the argument with the Swiss reformers, Luther found himself in the mid- to later 1520 at pains to explain how it was possible that Christ's body and blood could at the same time be both truly human (per the definition of Chalcedon) and present on many altars at one and the same time. He agreed fully with the biblical and creedal assertion that after the Ascension Jesus Christ is "seated at the right hand of the Father," which Zwingli had urged as proof that the humanity of Christ was locally circumscribed and for that reason could not be present at the altar. Luther rejected that claim, arguing that the Father's "right hand" is clearly a metaphor for a position of power and honor. The Father, after all, has not become enfleshed and therefore has no "right hand." To explain the true presence of Christ's body and blood, however, he made a rather elaborate appeal to Christology, particularly the communication of attributes (communicatio idiomatum). Christ's humanity, he argued, takes on certain attributes of divinity by virtue of its union with deity in the one Person, including that of ubiquity. Christ's body and blood, in short, are everywhere after the manner of God's own presence, that is, in a way that is not merely local-as in "that thing over there"-nor even angelic-a spiritual as opposed to a physical presence, or perhaps a multi-presence-but rather "repletive," that is, after the very manner in which God fills all things and yet cannot be reduced to them. The fullness of the divine presence is therefore a property, which although it does not belong properly to Christ's humanity is nevertheless communicated to it by virtue of the union with deity in the one Person, Christ the Lord. As proof for the qualitative changes the union effects in Christ's human body, Luther would appeal to biblical texts that seemed to portray the human body of Christ doing things that would be impossible for any other human body, most notably entering a room without using the door (see John 20 ).

This very presence is offered and received, in a mystical way, in the Lord's Supper. Pressed to explain why one needed to turn to the Lord's Supper to participate in Christ, since all of him was apparently present everywhere all of the time, Luther had recourse to the divine institution of the sacrament. Although Christ in his body and blood is 
indeed everywhere, he has promised to be present in a saving way only in and through the sacrament. Luther distinguished, in other words, between a divine omnipresence of Christ's body and blood that remains without saving effect, and the saving presence effected, per God's ordination, only within the Lord's Supper. The Lutheran theological tradition generally embraced Luther's notion that the humanity of Christ shares in the properties of divinity through the personal union, a genus of the communication of attributes that was soon labeled "majestic" (genus maiestaticum), because it entailed the humanity's participation in the divine rule over all things. Lutherans never formally committed themselves to Luther's understanding of ubiquity, however, although Lutheran theologians frequently defended it, including, in modified form, both Johannes Brenz and Martin Chemnitz. And in the seventeenth century Christology in relation to the genus maiestaticum became the source of the "kenosis controversy" (see Phil 2) in which the Lutheran faculties at Giessen and Tübingen argued over the exercise of Christ's kingly rule in the incarnation. Did Christ merely abstain from the exercise of his kingly rule over the creation in and through his humanity during the period of his humiliation (that is, from Bethlehem to Golgotha), or did he continue to exercise that rule even during that time, but in a hidden way? These questions suggest some of the important trajectories in Christology that would emerge from the Lutheran tradition, forged in its fundamentals in the eucharistic controversies of the early sixteenth century.

To be sure, the possibility of a united Protestant front against Rome did emerge briefly at the time of the Reformation, after a rapprochement between Lutheran and the Swiss and south German reformers on the Lord's Supper was codified in the Wittenberg Concord of 1536. Crafted long after both Zwingli and Oecolampadius were dead, this ecumenical agreement brought Luther's opponents well into the orbit of his eucharistic theology. The signers of the Concord, including Wolfgang Capito and Martin Bucer, agreed that "when the bread is distributed at the same time the body of Christ is present and truly offered" (Kittelson and Schurb: 125). This phraseology was understood to indicate that Christ was truly present in the bread while in the hands of the minister (that is, before its reception in the mouth of the communicant). In addition, the Concord affirmed that the "unworthy" also receive the true body and blood, a point that remained neuralgic among the Swiss. Within a few short years, however, this agreement unraveled under pressure from such opponents as Heinrich Bullinger in Zurich. Ecumenical agreement proved elusive for the Lutheran and the Reformed.

Turning now to the practice of the Lord's Supper, Luther and his followers emphatically rejected the reservation or use of the sacramental elements beyond the sacramental rite itself. Thus, there was to be no "tabernacling" or reservation of the sacrament, still less any monstrances or Corpus Christi processions. Instead, the bread and the wine were to be entirely consumed by those present for the mass. The Lutheran rejection of the so-called "private masses," moreover, where a priest celebrates mass without the congregation present, meant that there should never be consecrated elements without a congregation present to consume them. The Lutheran Reformation thus seemed to restrict sacramental activity rather insistently within the church walls. 
Though these ritual changes may seem like a mere footnote to the theological controversies described above, in fact such rules stand at an important intersection between what goes on in the church and what happens elsewhere. This is where church ritual meets the Christian people, that is, outside the church walls. The cultural historian Robert Scribner has drawn attention to the dense connections between "official" and "popular" religion in the region of the church's sacraments and liturgy in the early Reformation (Scribner 1987). In the later Middle Ages, he argued, the lines between the church's liturgy and what he called "folklorised ritual" were quite permeable. The exhibition of the sacrament in ritual processions outside the church bled quite naturally over into the application of sacred objects elsewhere: "Consecrated hosts could be used as love magic, for example, or scattered over a farm field to ensure agricultural fertility" (Scribner 1987: 36). The "sacramentals" (blessed objects such as palm branches and holy water), moreover, reduced even further the distance between the otherworldly power of the church and a magical view of the natural order. Protestant polemics frequently targeted such "superstitions." To the extent that Protestant theology emphasized the theocentric and monergistic elements of eucharistic practice-turning the Mass into a one-way street, understood as a benefit from God, but not a human sacrifice to God-just so, per Scribner, the reformers sometimes seemed intent on desacralizing the natural world. On the other hand, profoundly "Christianizing" trajectories were deeply embedded within Protestant catechesis, hymnody, and church life. Reformers like Luther wanted the average Christian to see her life as more, not less, an arena of divine activity and demonic opposition. The Lutheran Reformation thus brought new ways of understanding how the sacred was manifested in the profane, not a denial of that manifestation. To that extent, the transition between the sacramental religion of the later Middle Ages and that of the Lutheran Reformation is more subtle and elusive than our theological categories would sometimes suggest.

\section{SUggested ReAding}

H. G. Haile (1978); R. Kolb and T. J. Wengert (2000); E. Schlink (1961); E. W. Zeeden (2012).

\section{BIBLIOGRAPHY}

Bagchi, D. V. N. (2006), "Luther's Ninety-Five Theses and the Contemporary Criticism of Indulgences," in R. N. Swanson (ed.), Promissory Notes on the Treasury of Merits: Indulgences in Late Medieval Europe (Leiden: Brill), 331-355.

Brecht, M. (1985) Martin Luther, vol. 1: His Road to Reformation 1483-1521 (Minneapolis, MN: Augsburg Fortress).

Brecht, M. (1990) Martin Luther, vol. 2: Shaping and Defining the Reformation, 1521-1532 (Minneapolis, MN: Augsburg Fortress).

Brown, C. B. (2008), "Devotional Life, in Hymns, Liturgy, Music, and Prayers," in R. Kolb (ed.), Lutheran Ecclesiastical Culture, 1550-1675 (Leiden: Brill), 205-258. 
Burnett, A. N. (2011), Karlstadt and the Origins of the Eucharistic Controversy: A Study in the Circulation of Ideas (New York: Oxford University Press).

Haile, H. G. (1978), Luther: An Experiment in Biography (New York: Doubleday).

Hendrix, S. H. (2004), Recultivating the Vineyard: The Reformation Agendas of Christianization (Louisville, KY: Westminster John Knox).

Huovinen, E. (1997), Fides Infantium: Martin Luthers Lehre vom Kinderglauben (Mainz: Philipp von Zabern).

Kittelson, J. M. and K. Schurb (1986), "The Curious Histories of the Wittenberg Concord," Concordia Theological Quarterly 50 2: 119-138.

Kolb, R. and J. A. Nestingen (Eds.) (2001), Sources and Contexts of the Book of Concord (Minneapolis, MN: Fortress Press).

Kolb, R. and T. J. Wengert (Eds.) (2000), The Book of Concord: The Confessions of the Evangelical Lutheran Church (Minneapolis, MN: Fortress Press).

Luther, M. (1955-86), Luther's Works (Philadelphia, PA and St. Louis, MO: Fortress Press and Concordia Publishing House). [For the sacraments, see especially vols. 35-38.]

Mattox, M. L. (2003), "Offered and Received: Lutheran Theology and Practice of the Eucharist," Lutheran Forum 37 2: 33-44.

Oberman, H. A. (1966), Forerunners of the Reformation (New York: Holt, Rinehart \& Winston).

Rittgers, R. (2004), The Reformation of the Keys: Confession, Conscience and Authority in Sixteenth Century Germany (Cambridge, MA: Harvard University Press).

Schlink, E. (1961), Theology of the Lutheran Confessions (Philadelphia, PA: Fortress).

Scribner, R. W. (1987), "Ritual and Popular Belief in Catholic Germany at the Time of the Reformation," in Popular Culture and Popular Movements in Reformation Germany (London and Ronceverte: The Hambledon Press), 47-77.

Trigg, J. D. (1994), Baptism in the Theology of Martin Luther (Leiden: Brill).

Whitford, D. M. (2004), "Cura Religionis or Two Kingdoms: The Late Luther on Religion and the State in the Lectures on Genesis," Church History 73 1: 41-62.

Zeeden, E. W. (2012), Faith and Act: Medieval and Lutheran Practices Compared (St. Louis, MO: Concordia Publishing House). 